\title{
MEDICO-LEGAL ASSESSMENT OF PHYSICAL AND SEXUAL ASSAULTS' ALLEGATIONS AMONG ADOLESCENT AND ADULT FEMALES REFERRED TO MEDICOLEGAL DEPARTMENT OF MINISTRY OF JUSTICE AT ALEXANDRIA: A PROSPECTIVE STUDY
}

\author{
Zahraa K. Sobh ${ }^{\text {a }}$, Asmaa S. El-Banna ${ }^{\text {b }}$, Heba M. Menessi ${ }^{\text {C }}$ \\ ${ }^{\mathrm{a}}$ Lecturer of Forensic Medicine \& Clinical Toxicology, Alexandria University, Egypt \\ b \\ Associate Professor of Forensic Medicine \& Clinical Toxicology, Alexandria University, Egypt \\ ${ }^{\mathrm{c}}$ Head of Violence Against Women and Children Unit in the Medicolegal Department of \\ Ministry of Justice at Alexandria
}

\section{Corresponding Author: Zahraa Khalifa Sobh}

Lecturer of Forensic Medicine and Clinical Toxicology, Faculty of Medicine, University of Alexandria, Egypt.

Email: z_khalifa2017@yahoo.com, zahraa.sobh@alexmed.edu.eg

\begin{abstract}
Background: Violence against women (VAW) is a universal crime cutting across cultural and religious barriers violating females' human rights. The aim of the study: was to assess physical and sexual assaults allegations of adolescent and adult females Subjects and Methods: A prospective study included all females above the age of 12 years old who were referred to the Medicolegal Department of Ministry of Justice at Alexandria to assess their physical and sexual assaults allegations. The study period was 6 months (from the $1^{\text {st }}$ August 2018 till the end of January 2019). Results: A total of 92 females alleged violence (60 sexual and 32 physical assault) were encountered in the study. Nearly three quarters $(71.7 \%)$ of the females with sexual assault allegations were adolescents, whereas more than three quarters $(78.1 \%)$ of those with claims of physical abuse were adults. About half (45\%) of sexual allegations were attributed to friends, whereas, in physical violence, more than two-thirds $(68.7 \%)$ of the cases were intrafamilial. A half of physical violence claims were simple wounds and the other half were serious injuries in the form of traumatic abortion, infirmities, stab, and firearm injuries. Considering sexual allegations, rape represented more than half $(56.7 \%)$ of sexual assault claims, followed by sodomy (20\%), mixed rape and sodomy $(11.7 \%)$, intercrural intercourse (4\%), and attempt of rape $(3 \%)$.
\end{abstract}


Regarding medico-legal finding; clear evidence of assault was elucidated in 50\% and $35.8 \%$ of physical and sexual allegations respectively; while no evidence of alleged assault could be detected in $25 \%$ and $40.2 \%$ of physical and sexual claims respectively. No firm evidence with the possible occurrence of the alleged assault was the condition in $25 \%$ and $23.8 \%$ of physical and sexual allegations respectively. Conclusion: Evaluation of physical abuse yields solid medicolegal opinion in most of the cases. On the contrast, the nature of genital and anal injuries was much more confusing that raises a lot of uncertainties. Therefore, rapid medicolegal assessment of the victims of sexual crimes along with the cautious interpretation of findings is advisable.

Keywords: Physical violence; Sexual assault; Medicolegal assessment; Allegations; Females; Alexandria.

\section{INTRODUCTION}

Violence against women (VAW) is one of the most widespread violations of human rights that extended worldwide. Though VAW is crossing boundaries, the magnitude of the problem is greatly variable from a country to another. The extent of such violation is proportionate to the extent of gender-based discrimination in society. Therefore, different forms of VAW could not be considered as random sporadic individual incidents, rather than a provocation of deeply rooted cultural believes of male dominance and gender inequality. (Violence Against Women In Politics, New York, 2018)

In 2016, the World Health Organization (WHO) conducted global estimates that revealed that one in three women have experience of physical and/or sexual violence in their lifetime. (Guedes et al., 2016, WHO, 2017)

Considering the Eastern Mediterranean region, it ranked as a second high region in the prevalence of VAW (37\%) following South East Asia (37.7\%). The prevalence of VAM declines in civilized regions and does not exceed $30 \%$. (WHO, 2017)
Violence against women could be categorized into physical, sexual or psychological harm. Women could be subjected to any form of violence at any stage of their lives from adulthood to aging and such violations could take place in both the private and the public spheres. (UN Women New York, 2012)

Since Violations of human rights are greatly impacting not only the victims themselves but also their families and societies, the researchers in all related fields are concerned with investigations of different aspects of escalating violence. (Alvarado et al., 2018)

The allegations of physical violence against women are frequent and include deliberate use of any sort of physical force such as blunt trauma or burn and firearm injuries with the intent of causing injury, infirmity or death. (Owusu-Addo et al., 2018)

Coercion of an individual to engage in any form of unwanted sexual contact or behavior is considered sexual assault. In this type of assault, a careful and rapid collection of biological specimens and right interpretation of the findings are important to protect the rights of both alleged victim 
and the accused offender through avoiding wrongful conviction and re-victimization. ((Yount et al., 2017, Ludes et al., 2018)

The forensic examiner plays a critical role in the assessment of women with an allegation of physical and sexual assaults. According to the legal system in Egypt, law enforcement officers accompany public prosecution teams to crime scenes to examine the evidence and question witnesses. (Egyptian council of women, 2015)

Along with immediate health care, proper medicolegal evaluation of the victims is mandatory. The medicolegal assessment includes thorough history taking and complete general and local examination, in addition to a collection of relevant biological evidence. The opinion of the forensic examiner stated in the medicolegal report is critical in the verification of victim allegations. (Laukkanen, 2014)

Though the statistics for physical and sexual assaults against women in Egypt are limited, social and legal indicators are pointing to increased violence. Alexandria is the second-largest city in Egypt, with a population more than 5.200 million according to Central Agency for Public Mobilization and Statistics estimate in 2017 census. (CAPMAS 2017, UN Human Rights, 2019)

The current research aimed at assessing physical and sexual assaults allegations of adolescent and adult females referred to the Medicolegal Department of the Ministry of Justice at Alexandria.

\section{SUBJECTS AND METHODS}

The current study was a prospective cross-sectional study that included all females above the age of 12 years old who were referred to Violence Against Women and Children Unit in Medicolegal
Department of Ministry of Justice at Alexandria to assess their physical and sexual assaults allegations during a period of 6 month (from the $1^{\text {st }}$ August 2018 till the end of January 2019).

The research has been performed under the agreement of General Director of Egyptian Forensic Medicine Authority (EFMA) and Ethics Committee of the Faculty of Medicine, Alexandria University, FWA number: 00018699, approval serial number: 0304060. Informed consents were obtained from all subjects before participation in the study.

Each alleged victim was subjected to the following:

1- Legal procedures:

- Careful reviewing of public prosecution order and victim documents.

- Confirmation of the identity from identity card of the victim or victim legal guardian (if less than 16 years) along with obtaining her inked fingerprints.

2- Interviewing the victim to obtain information regarding the following:

- Victim characteristics: age, marital status, residence, education, and employment.

ssault characteristics: number of the assailant(s), assailant(s) relationship to the $\operatorname{victim}(\mathrm{s})$, place of the assault, frequency of assault (s) and the time lapse between examination and last assault, and manner of the alleged assault.

3- Medico-legal examination:

a. General examination:

Comprehensive general examination was carried out that include proper documentation of all visible injuries all over the body (type, location, direction, shape, dimensions of injuries. 
b. Local examination of genital or anal region in sexual assaults allegations:

The humanitarian aspect of examination in cases of sexual assault should be considered. The assessment is only done in the presence of a third individual and the patient must be informed by evaluation procedures in details including before starting the examination.

\section{i. Examination of genitalia: (Ludes et} al., 2018)

The potential victim was examined in lithotomy position under a direct light with proper flexion and abduction of the hip joint. The labia majora were grasped between the thumb and index finger and gently pulled outward and slightly upward to expose the introitus. Then, careful visualization and documentation were done using the colposcope.

A colposcope is a free-standing, binocular microscope on wheels that provides an excellent magnified image along with a secured photographic record of the findings.

The following structures were inspected properly for recent and old injuries: perineum; pubic area; labia majora; labia minora; clitoris; posterior fourchette; fossa navicularis and hymen.

The vaginal swab was only done within 7 days post-assault in alleged vaginal assaults using special sterile cotton swab that was carefully sealed and labeled to maintain the chain of custody and sent to the laboratory.

ii. Anal region examination: (Stark, 2011, Ludes et al., 2018)

The potential victim was examined in knee-chest with knees apart and the examiner pressed a thumb outward on the leading edge of the gluteus maximus to expose anal region that was carefully visualized and documented using colposcope. The condition of the anal sphincter (anal sphincter tone and reflex) along with the presence or absence of anal injuries should be considered. If the examination was conducted within 3 days following an alleged offense, a special sterile cotton swab was used to obtain anal swab that was carefully sealed and labeled and sent to the laboratory.

All swabs that were obtained in the cases of alleged sexual assault were tested for the presence or absence of spermatozoa.

4. Medicolegal finding:

On the view of victim documents and prosecution order along with medicolegal assessment, the forensic examiner could find evidence. However, not in all situations, the medicolegal evidence is firm (either firm positive or negative). Therefore, medicolegal evidence could be one of the following:

1- Positive evidence (clear evidence of alleged assault): Physical violence could be proved by matching the type and age of injury with alleged instrument and time of incidence (consistent history), whereas the sexual assaults usually confirmed by the presence of recent anogenital injuries and/or by detection of spermatozoa. Moreover, pregnancy is sharp evidence of sexual violence.

2- Negative evidence (no evidence of alleged assault): often bases on lack of any relevant evidence in relation to an alleged crime or presence of self-inflicted (fabricated) trauma.

3- No firm evidence (possible occurrence of alleged assault): The uncertainty often raised during evaluation of physical as well as sexual violence when the examination is too late that allows healing of injuries and loss of evidence. Moreover, the presence of old anogenital injuries along with wide orifices could allow complete 
penile penetration without evident recent injuries.

Statistical analysis of the data:

Data and measurements were recorded then analyzed using IBM SPSS software package version 20.0 .

\section{RESULTS}

A total of 92 females were included in the study, nearly two-thirds of them (60 cases) with an allegation of sexual abuse and the rest were with claims of physical violence.

Figure (1) shows the numbers of adult females that were medicolegally assessed in Violence against Women and Children Unit in the Medicolegal Department of Ministry of Justice at during a period of 6 months (from the 1st August 2018 till the end of January 2019). The allegations of sexual assaults out weighted physical violence in all months except in November. It is worth mentioning that half of the cases of sexual assaults presented in August and September.

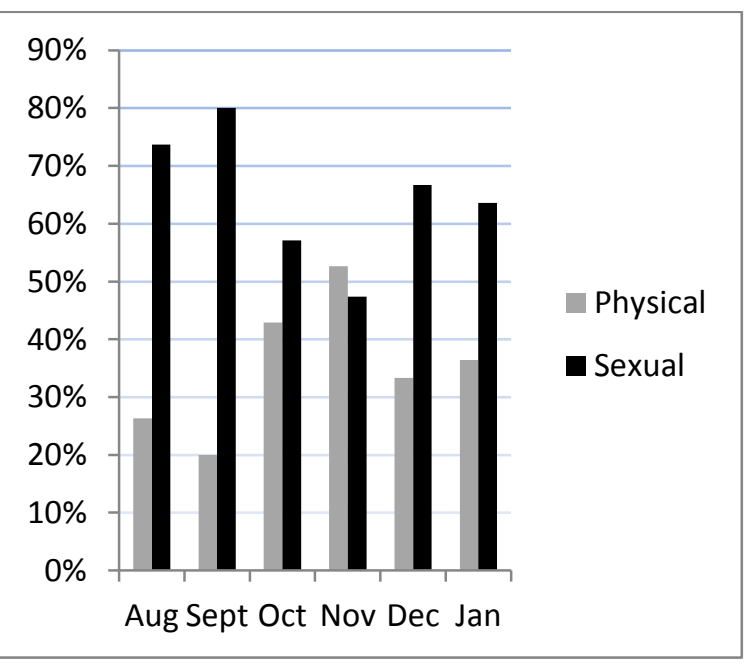

Figure (1): Distribution of adolescent and adult females with allegations of physical and sexual assault $(n=92)$ over the studied months.

\section{- Victim characteristics:}

Table (1) shows the demographic characteristics of the potential victims regarding the following:

Age: The age of the cases with sexual assaults allegations ranged from 12 to 51 years and nearly similar range in the cases with claims of physical violence (12-52 years). Though, the mean age was significantly higher in those with claims of physical violence (29.2 \pm 12.3 years) compared to others with sexual assaults allegations $(19.4 \pm 8.7$ years $)$, where $t=4.027$ and $\mathrm{p}=<0.001$.

Nearly three quarters $(71.7 \%)$ of the females with sexual assault allegations were adolescents (from 12 to less than 18 years old), whereas more than three quarters (78.1\%) of those with claims of physical abuse were adults (exceeding the age of 18 years).

Marital Status: The majority (90\%) of females with sexual assaults allegations were not officially married before. Nevertheless, nearly three quarters $(71.9 \%)$ of those with physical violence claims were married (either currently or had a history of marriage).

Residence: Nearly two-thirds $(65 \%)$ of adult females with sexual assaults allegations were resident in rural areas. On the other hand, no major difference was detected among cases with physical violence claims considering the residence.

Education: About half (48.3\%) of adult females with allegations of sexual assault had technical education, followed by illiterates (36.6\%). Though, no major difference was found among cases with physical violence claims regarding education. 
Table (1): Characteristics of the potential victims with allegations of physical and sexual assaults.

\begin{tabular}{|c|c|c|}
\hline & $\begin{array}{c}\text { Physical } \\
(n=32)\end{array}$ & $\begin{array}{c}\begin{array}{c}\text { Sexual } \\
(n=60\end{array} \\
\end{array}$ \\
\hline \multicolumn{3}{|l|}{ Age (years) } \\
\hline $\begin{array}{l}\text { 12- } 18 \\
\text { (adolescent) }\end{array}$ & $7(21.9 \%)$ & $\begin{array}{c}43 \\
(71.7 \%)\end{array}$ \\
\hline$\geq 18 \quad$ (adult) & $25(78.1 \%)$ & $\begin{array}{c}17 \\
(28.3 \%)\end{array}$ \\
\hline $\begin{array}{l}\text { Median (Min. } \\
\text { - Max.) }\end{array}$ & $\begin{array}{c}29.5 \\
(12-52)\end{array}$ & $\begin{array}{c}16 \\
(12-51)\end{array}$ \\
\hline Mean $\pm \mathrm{SD}$ & $29.2 \pm 12.3$ & $\begin{array}{c}19.4 \pm \\
8.7\end{array}$ \\
\hline \multicolumn{3}{|l|}{ Marital status } \\
\hline $\begin{array}{l}\text { Not married } \\
\text { before }\end{array}$ & $9(28.1 \%)$ & $54(90 \%)$ \\
\hline $\begin{array}{l}\text { Married/ } \\
\text { Divorced }\end{array}$ & $23(71.9 \%)$ & $6(10 \%)$ \\
\hline \multicolumn{3}{|l|}{ Residence } \\
\hline Urban & $14(43.7 \%)$ & $21(35 \%)$ \\
\hline Rural & $18(56.2 \%)$ & $39(65 \%)$ \\
\hline \multicolumn{3}{|l|}{ Education } \\
\hline Illiteracy & $9(28.1 \%)$ & $\begin{array}{c}22 \\
(36.6 \%)\end{array}$ \\
\hline $\begin{array}{l}\text { Technical } \\
\text { education }\end{array}$ & $11(34.3 \%)$ & $\begin{array}{c}29 \\
(48.3 \%)\end{array}$ \\
\hline $\begin{array}{l}\text { University } \\
\text { education }\end{array}$ & $12(37.5 \%)$ & $9(15 \%)$ \\
\hline
\end{tabular}

-Assault characteristics:

Table (2) shows the characteristics of alleged sexual and physical assaults regarding the following:
Table (2): Characteristics of alleged sexual and physical assaults.

\begin{tabular}{|c|c|c|}
\hline & $\begin{array}{c}\text { Physical } \\
(\mathrm{n}=32)\end{array}$ & $\begin{array}{c}\text { Sexual } \\
(n=60)\end{array}$ \\
\hline \multicolumn{3}{|c|}{ Number of assailant(s) } \\
\hline 1 & $28(87.5 \%)$ & $51(85 \%)$ \\
\hline$>1$ & $4(12.5 \%)$ & $9(15 \%)$ \\
\hline \multicolumn{3}{|c|}{ Assailants relationship to victim } \\
\hline Family member & $22(68.7 \%)$ & $15(25 \%)$ \\
\hline Friend & $4(12.5 \%)$ & $27(45 \%)$ \\
\hline Neighbor & $5(15.6 \%)$ & $6(10 \%)$ \\
\hline Stranger & $1(3.1 \%)$ & $12(20 \%)$ \\
\hline \multicolumn{3}{|c|}{ Place of assault(s) } \\
\hline Victim home & $17(53.1 \%)$ & $21(35 \%)$ \\
\hline Assailant home & $5(15.6 \%)$ & $\begin{array}{c}26 \\
(43.3 \%)\end{array}$ \\
\hline Outdoors & $10(31.3 \%)$ & $\begin{array}{c}13 \\
(21.7 \%)\end{array}$ \\
\hline \multicolumn{3}{|c|}{ Frequency of assault(s) } \\
\hline 1 & $18(56.3 \%)$ & $\begin{array}{c}26 \\
(43.3 \%)\end{array}$ \\
\hline$>1$ & $14(43.8 \%)$ & $\begin{array}{c}34 \\
(56.7 \%)\end{array}$ \\
\hline \multicolumn{3}{|c|}{ Time lapse to examination (days) } \\
\hline 1 & $5(15.6 \%)$ & $8(13.3 \%)$ \\
\hline 2 & $4(12.5 \%)$ & $7(11.7 \%)$ \\
\hline 3 & $5(15.6 \%)$ & $8(13.3 \%)$ \\
\hline Up to 7 & $12(37.5 \%)$ & $12(20 \%)$ \\
\hline$>7$ & $6(18.8 \%)$ & $\begin{array}{c}25(41.7 \\
\%)\end{array}$ \\
\hline \multicolumn{3}{|c|}{ Type of alleged assault } \\
\hline Misdemeanor & $16(50 \%)$ & $0(0 \%)$ \\
\hline Felony & $16(50 \%)$ & $\begin{array}{c}60 \\
(100 \%) \\
\end{array}$ \\
\hline
\end{tabular}

Number of the assailant(s): The violence was attributed to one assailant in the majority of the victims either with allegations of physical or sexual violence. 
Relationship to the assailant(s): The majority of physical abuse $(96.9 \%)$ and sexual abuse $(80 \%)$ was committed by wellknown or familiar persons. Regarding sexual assaults, about half (45\%) of the allegations were attributed to friends, and one quarter (25\%) of assaults were attributed to family members. Nevertheless, in the cases of physical violence, more than two-thirds $(68.7 \%)$ of the cases were attributed to family members.

Considering alleged sexual crimes committed by family members, more than half $(53.3 \%)$ of the cases could be described as incest as follow: Three father-daughter, three stepfather- wife's daughter, one case the assailant was her uncle and the last case the assault was committed by his spouse's brother. Also, $20 \%$ of sexual violence among the family was intimate partner violence where the husbands accused of unnatural sexual acts. Non-cohabitating family members were responsible for more than a quarter $(26 \%)$ of sexual claims.

Regarding physical violence within the family, more than half $(59 \%)$ of cases were intimate partner physical violence and the rest of the allegations (41\%) were attributed to non-cohabitating family members.

Place of Assault: Assailant home was the commonest place of alleged sexual crimes $(43.3 \%)$, followed by victim home (35\%), and outdoors $(21.7 \%)$, whereas more than half $(53.1 \%)$ of physical assaults were claimed to be in victim home.

Frequency of assault(s): More than half $(56.7 \%)$ of sexual assaults were alleged to be repeated more than once, whereas $56.3 \%$ of physical violence was reported to be the first attack.

Time-lapse till examination: Considering the period between the last violent incident and the current medico-legal assessment, $58.3 \%$ of cases with claimed sexual offense and $81.2 \%$ of females with physical violence allegations were examined within one week.

Type of alleged assault: Table (3) revealed that half of the females with physical violence claims were presented with simple wounds in the form of abrasions, contusions and cut wounds (misdemeanors). While, the other half complained of serious injuries in the form of traumatic abortion, infirmities, Stab, and firearm injuries (felonies). Infirmities reported in the present work were mainly limitations in limb movements either due to fracture with mal-union following blunt trauma or nerve or tendon injuries by a sharp instrument, in addition to one case of blunt injury to the eye with diminution of vision to a perception of light.

Table (3): Types of alleged physical assaults.

\begin{tabular}{|c|l|c|}
\hline \multicolumn{2}{|c|}{ Alleged physical assault } & (n=32) \\
\hline $\begin{array}{c}\text { Misdemeanors (simple } \\
\text { injuries) }\end{array}$ & $\mathbf{1 6}(\mathbf{5 0 \%})$ \\
\hline \multirow{2}{*}{ Felonies (serious injuries) } & Abrasions & $7(21.9 \%)$ \\
\cline { 2 - 3 } & Contusions & $5(15.6 \%)$ \\
\hline & $\begin{array}{l}\text { Cut wounds } \\
\text { Traumatic } \\
\text { abortions }\end{array}$ & $8(25 \%)$ \\
\cline { 2 - 3 } & Infirmities & $5(15.6 \%)$ \\
\cline { 2 - 3 } & $\begin{array}{l}\text { Stab } \\
\text { wounds }\end{array}$ & $2(6.3 \%)$ \\
\cline { 2 - 3 } & $\begin{array}{l}\text { Firearm } \\
\text { injuries }\end{array}$ & $1(3.1 \%)$ \\
\hline
\end{tabular}

It is worth mentioning that all sexual assaults that were presented in the current study are considered felonies according to Egyptian law. The allegations of vaginal intercourse (rape) represent more than half $(56.7 \%)$ of sexual assault claims, followed 
by allegations of sodomy (20\%), mixed vaginal and anal penetration (11.7\%), intercrural intercourse (4\%), and attempt of rape (3\%). (fig. 2)

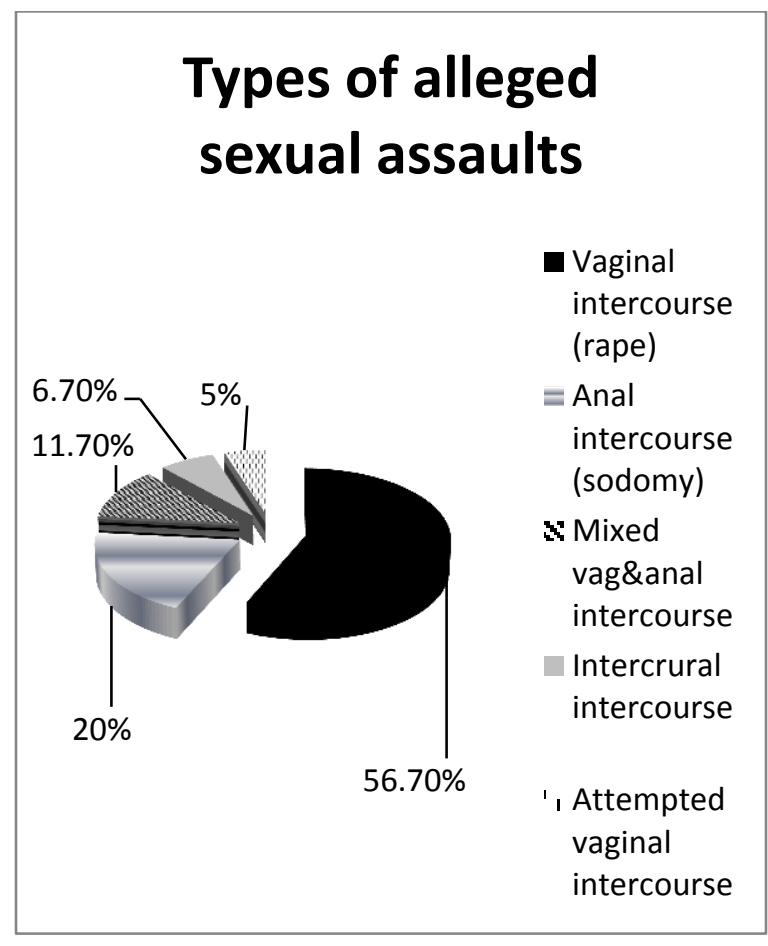

Figure (2): Types of alleged sexual assaults.

\section{- Medico-legal examination:}

\section{A- General examination:}

Table (4): revealed the results of a comprehensive general examination of potential victims with sexual and physical allegations (92 adult female) regard the following:
Table (4): Characteristics of injuries demonstrated during a general examination of potential victims with sexual and physical allegations.

\begin{tabular}{|c|c|c|}
\hline & $\begin{array}{c}\text { Physical } \\
(\mathrm{n}=32)\end{array}$ & $\begin{array}{l}\text { Sexual } \\
(n=60)\end{array}$ \\
\hline \multicolumn{3}{|c|}{ Presence of injuries } \\
\hline No injury & $5(15.6 \%)$ & $39(65 \%)$ \\
\hline Injury & $27(84.3 \%)$ & $21(35 \%)$ \\
\hline \multicolumn{3}{|c|}{ Anatomical location of injury } \\
\hline Head & $10(31.3 \%)$ & $5(8.3 \%)$ \\
\hline Upper limp & $20(62.5 \%)$ & $7(11.7 \%)$ \\
\hline Lower limp & $0(0 \%)$ & $9(15 \%)$ \\
\hline Chest & $3(9.4 \%)$ & $5(8.3 \%)$ \\
\hline Abdomen & $2(6.3 \%)$ & $1(1.7 \%)$ \\
\hline Back & $4(12.5 \%)$ & $2(3.3 \%)$ \\
\hline \multicolumn{3}{|l|}{ Type of injury } \\
\hline Abrasion & $7(21.9 \%)$ & $17(28.3 \%)$ \\
\hline Contusion & $5(15.6 \%)$ & $9(15 \%)$ \\
\hline Cut & $8(25 \%)$ & $2(3.3 \%)$ \\
\hline Stab & $2(6.3 \%)$ & 0 \\
\hline Burn & $1(3.1 \%)$ & 0 \\
\hline Bite & 0 & $2(3.3 \%)$ \\
\hline Firearm & $1(3.1 \%)$ & 0 \\
\hline Fracture & $3(9.4 \%)$ & $2(3.3 \%)$ \\
\hline
\end{tabular}

Categories are not mutually exclusive (not added up to $100 \%$ )

Presence of injuries: No injuries could be detected during general examination on nearly two thirds $(65 \%)$ of females with sexual assaults, whereas injuries were present in most of the cases (84.3\%) with physical assaults allegation. It is worth noting that multiple or different types of injuries were reported in the same victim and might involve multiple sites in her body.

Anatomical location of the injury: The upper limbs were the commonest anatomical site of injuries $(62.5 \%)$ in cases of physical abuse allegations followed by the head region (31.3\%). Nevertheless, among 21 cases of alleged sexual assault with positive injuries, lower limbs were the 
favorable area of trauma $(n=9)$ followed by upper limbs $(n=7)$ that represents $15 \%$ and $11.7 \%$ respectively.

Type of injury: Abrasions were the most common injury in the cases with sexual crimes, while cut wounds were the commonest injury in cases with physical violence claims. Burn and serious injuries such as firearm injuries and stab wounds were demonstrated only in cases of physical violence but not in sexual crimes.

\section{Medico-legal finding in physical assaults allegations:}

\section{1- Positive evidence (clear evidence of} alleged assault):

Physical injuries could be firmly proved in 16 females who represent $50 \%$ of females with claims of physical trauma. The proved injuries were as the following: 3 abrasions, 2 cut wounds, 5 contusions, 5 infirmities, and one firearm injury.

2- Negative evidence (no evidence of alleged assault): Self- inflicted injuries were present in 8 females (6 cases with cuts and 2 cases with abrasions).

3- No firm evidence (possible occurrence of alleged assault): in eight females complained of abortion in relation to blunt abdominal traumas.

\section{B-Local examination of genital or anal region in sexual assaults allegations: a- Vaginal intercourse} (rape):

Table (5): revealed the results of a genital examination of 41 potential victims with allegations of vaginal penetration (34 females who alleged rape only and seven females who alleged rape along with sodomy).

Hymenal tear: The hymen was intact with the absence of recent and old tears in nearly half $(48.8 \%)$ of females with an allegation of vaginal intercourse, whereas recent tears were present only in four cases. Old tears were demonstrated in 17 females who represented $41.5 \%$, though three of them were married before and the hymenal injury could not be attributed to sexual crimes.

Vaginal swab: The vaginal swab was positive for the presence of spermatozoa in only 8 females with an allegation of vaginal intercourse $(19.5 \%)$ and spermatozoa could not be detected in vaginal swabs of 17 female $(41.5 \%)$. The rest of the cases with rape allegations were presented after 7 days when vaginal swabs were no longer done.

\section{Medico-legal finding:}

1- Positive evidence (clear evidence of alleged assault): Rape could be proved only in 14 females $(34.1 \%)$ with clear evidence, as follows; 6 positive swabs; 4 pregnancies; 2 positive swabs along with recent hymenal tear and two cases with an only recent tear in the hymen.

2- Negative evidence (no evidence of alleged assault): No recent injuries or spermatozoa could be detected in 17 females who represent $41.5 \%$ with allegations of vaginal penetration.

3- No firm evidence (possible occurrence of alleged assault): In 10 females who represented about a quarter of females with rape claims, no firm medicolegal opinion could be taken because of the presence of old hymenal injuries along with wide vaginal orifices to extent that could allow complete penile penetration without leaving an evident recent rape. 
Table (5): Vaginal examination of females with allegations of vaginal intercourse and the medicolegal finding.

\begin{tabular}{|c|c|}
\hline $\begin{array}{c}\text { Vaginal } \\
\text { intercourse }\end{array}$ & $n=41$ \\
\hline \multicolumn{2}{|l|}{ Hymenal tear } \\
\hline Not present & $20(48.8 \%)$ \\
\hline Recent & $4(9.8 \%)$ \\
\hline Old & $17(41.5 \%)$ \\
\hline \multicolumn{2}{|l|}{ Vaginal swab } \\
\hline $\begin{array}{l}\text { Positive for } \\
\text { spermatozoa }\end{array}$ & $8(19.5 \%)$ \\
\hline $\begin{array}{l}\text { Negative for } \\
\text { spermatozoa }\end{array}$ & $17(41.5 \%)$ \\
\hline Not done (>7days) & $16(39.0 \%)$ \\
\hline \multicolumn{2}{|c|}{ Medico-legal finding } \\
\hline Positive evidence & $14(34.1 \%)$ \\
\hline Negative evidence & $17(41.5 \%)$ \\
\hline No firm evidence & $10(24.4 \%)$ \\
\hline
\end{tabular}

\section{b. Anal intercourse (sodomy):}

Table (6): revealed the results of an anal examination of 19 potential victims with allegations of anal penetration (12 females who alleged sodomy only and seven females who alleged sodomy along with rape).

Anal fissure: On anal examination, Seven cases that represented more than onethird $(36.8 \%)$ of the females with alleged sodomy had an old anal fissure. Six cases with recent anal tears and another 6 cases with no anal injuries were present and each represented $31.6 \%$ of the cases of sodomy allegations.

Anal reflex and sphincter tone: Diminished anal reflex and sphincter tone was the condition of more than two-third $(68.4 \%)$ of the females with an allegation of anal penetration.
Anal swab: Spermatozoa could be detected only in two cases that represent $10.5 \%$ of females with sodomy claims, and the anal swab was negative for the presence of spermatozoa in more than quarter (26.3\%) of them. The rest of the cases were presented after 3 days following an alleged assault when the anal swabs were no longer useful.

\section{Medicolegal finding:}

1- Positive evidence (clear evidence of alleged assault): Sodomy could be proved only in seven females (36.8\%), five of them with recent anal fissures and subnormal anal tone and reflex, one case with recent anal fissure and subnormal anal tone and reflex along with positive anal swab, and another case with only positive anal swab.

2- Negative evidence (no evidence of alleged assault): No recent injuries or spermatozoa could be detected in six females who represented $31.6 \%$ with allegations of anal penetration.

3- No firm evidence (possible occurrence of alleged assault): In six females who represented $31.6 \%$ of females with sodomy claims, no firm medicolegal opinion could be taken because of the presence of old anal injuries along with wide anal orifices to extent that could allow complete penile penetration without leaving a recent evidence along with non-detection of spermatozoa. 
Table (6): Anal examination of females with allegations of anal intercourse and medicolegal finding.

\begin{tabular}{|c|c|}
\hline Anal penetration & $(n=19)$ \\
\hline \multicolumn{2}{|l|}{ Anal fissure } \\
\hline Not present & $6(31.6 \%)$ \\
\hline Recent & $6(31.6 \%)$ \\
\hline Old & $7(36.8 \%)$ \\
\hline \multicolumn{2}{|c|}{ Anal reflex and sphincter tone } \\
\hline Normal & $6(31.6 \%)$ \\
\hline Diminished & $13(68.4 \%)$ \\
\hline \multicolumn{2}{|l|}{ Anal swab } \\
\hline $\begin{array}{l}\text { Positive for } \\
\text { spermatozoa }\end{array}$ & $2(10.5 \%)$ \\
\hline $\begin{array}{l}\text { Negative for } \\
\text { spermatozoa }\end{array}$ & $5(26.3 \%)$ \\
\hline Not done (>3days) & $12(63.2 \%)$ \\
\hline \multicolumn{2}{|l|}{ Medico-legal opinion } \\
\hline Positive evidence & $7(36.8 \%)$ \\
\hline Negative evidence & $6(31.6 \%)$ \\
\hline No firm evidence & $6(31.6 \%)$ \\
\hline
\end{tabular}

\section{c. Intercrural intercourse:}

Four females with an allegation of intercrural intercourse were assessed in the current study. The assault could not be proved only in one case, due to lack of any evidence of a sexual crime. Nevertheless, it could be confirmed in the other three females as spermatozoa were detected in the external vaginal swabs of two cases and the pregnancy test was tested positive in the third one.

\section{d. Attempted vaginal intercourse:}

In the current study, three females with an allegation of attempted rape were evaluated and the sexual offense could not be confirmed due to lack of relevant evidence of sexual violence.

\section{DISCUSSION}

Nowadays, there is a growing concern about the increasing rate of physical and sexual abuse worldwide because of their serious morbid health consequences. Beside immediate health care, a proper medicolegal assessment of the victims is of critical value. (El-Elemi et al., 2011, Steine et al., 2012)

Thought, the social and legal indicators are pointing to escalating violence against women in Egypt, proper medicolegal description of physical and sexual assaults are quite deficient. Therefore, the current study was a prospective cross-sectional study that included all females above the age of 12 years old referred to the Medicolegal Department of Ministry of Justice at Alexandria to assess their physical and sexual assaults allegations during a period of 6 months (from the 1st August 2018 till the end of January 2019).

The adolescence is the transition period from childhood to adulthood which ranged from 12 years (average pubertal onset) to 18 years of age that is why the study included only those who exceed the age of 12 years old to ensure their sexual maturity. Also, the age of 18 years was taken into consideration because it is the age of the legal adulthood above which the female could give free consent to the sexual act. (Jaworska and MacQueen, 2015, Sharaf El-Din et al., 2015)

Only 92 females were referred for verification of their abuse claims over a period of 6 months, such number is incomparable to the number of Alexandria governorate residents that could reflect under-reporting of the violence against women in Alexandria governorate. A similar under-reporting was evident in previous studies conducted in other in Egyptian governorates that could be attributed to 
social and legal factors. (Hilal et al., 2006, El-Elemi et al., 2011, Sharaf El-Din et al., 2015)

In the current work, the allegations of sexual assaults outnumbered physical violence allegations (constituted nearly twothird of the female). This could be explained by high social concern regarding sexual assaults as honor-related crimes. On the other hand, physical abuse could be more socially acceptable that often ended with conciliations before taking legal actions.

The social acceptability of violence against women is based on the beliefs of male dominance and gender inequality. Moreover, some challenges could compel some women to withstand abuse, such as; having the duty to look after her aging partner, with fear of living alone or loss of economic support or even loss of custody of children and sometimes the presence of low self-esteem from repeated abuse rendering the abuse tolerated and ignored to keep her family together. (Kernbach-Wighton 2014)

In the present study, the allegations of sexual assaults out weighted physical violence in all months except in November. There was actually a false increase in physical abuse allegation in November as four cases of fabricated wounds were diagnosed by medico-legal examination. It was also obvious that summer months had a higher incidence of sexual offenses as half of the females with sexual assaults allegations presented in August and September. The increasing numbers of sexual crimes in summer months could be attributed to much spare time, wakefulness for late hours and physical approximation with mixing in resorts that are in agreement with Sukul et al., 2009 and Sharaf El-Din et al., 2015.

In addition, McLean, (2007) and Hwang et al., (2010) attributed the higher incidence of sexual assaults in summer to the physiological stimulant effect of higher temperature and longer sunshine hours, in addition to increased visibility and accessibility to larger number of people as being in public places for most of the time.

In the present work, the mean age of females with physical allegations was significantly higher than that of those with sexual assaults claims. Moreover, more than three-quarters of those with claims of physical traumas were legally adults, whereas nearly three-quarters of the females with sexual offense allegations were minors.

Considering the marital status, nearly three-quarters of females complaining from physical assaults were married or divorced, whereas the majority of those with sexual crimes allegations were not married before.

The prevalence of sexual offences among minors who were not married before was in agreement with other studies (Hilal et al.,, 2006, Hassan et al., 2007, Arif et al., 2014 and Sharaf El-Din et al., 2015) and could be attributed to physical attraction of adolescents to offenders and being have low experience and immaturity together with lack of care from their guardians in these teen ages indulges them in boyfriend relation. Also, the current work could point to the residence in rural areas together with illiteracy or low educational level as risk factors for sexual assaults

In the present study, most assaults were attributed to a single perpetrator that was in accordance with Santos et al., 2006 and Arif et al., 2014 who reported that only 12\% and $26 \%$ of their cases respectively were assaulted by more than one perpetrator.

The present work showed that $96.9 \%$ of physical abuse and $80 \%$ of sexual abuse was committed by well-known or familiar persons, which were consistent with Rege et 
al., 2017 and Pal et al., 2018. Moreover, another study revealed that in many instances, the assailants of rape were authority or trusted figures, old teachers, job supervisors, and relatives. (Riggs et al., 2000) So, females should be advised to avoid being alone with males whatever their relationship. (Badejoko et al., 2014)

It was noted that physical assaults were intra-familial in more than two-thirds of the cases and intimate partner violence (IPV) constituted $59 \%$ of them. Therefore victims homes were the commonest places of the violent physical attacks. This could also explain why $43 \%$ of the victims withstand more than one violent attack before reporting. This was in accordance with the results of Regueira-Diéguez et al., 2015.

On the other hand, boyfriends were the commonest assailants in the cases of sexual offenses $(45 \%)$ which could be described as date-rape. Therefore the assailants' homes were the commonest places of such crimes. The current results were in agreement with the study that was conducted in Pakistan by Arif et al., 2014 who stated that more than half of sexual assault offenses occurred in assailant home.

Acceptance of sexual acts could be elucidated by certain observations as the repetition of alleged assault more than once in more than half of victims, a delayed presentation more than a week in more than third of victims, in addition to the absence of extra-genital injuries in nearly two-thirds of them.

In the current work, a quarter of alleged sexual abuse cases was intra-familial and more than half of them were incest. The commonest type of incest encountered in the present study was Father-daughter or stepfather-wife's daughter, this was in agreement with El-Elemi et al., 2011. This constituted a problem in reporting the case where the parent guardian was the offender, thus commonly a delayed presentation with negative finding is the case. The delayed reporting with the subsequent delayed examination was also reported by other similar studies (Janisch et al., 2010 and Arif et al., 2014).

The delay in reporting of assault could be due to several factors such as victim fear of offender or parents or parents' fear of social stigma and indignity with concern about the future of survivor's marriage. Moreover, decreased awareness about the victim's rights or fear to confront the legal system, in addition to fear of the impact of legal processes on the family if the assailant was a family member. All these factors may play a role of underreporting the actual assault incidence. (Arif et al., 2014) This results in a decrease in conviction rate which in turn, encourages re-victimization.

In the present study, assaults are classified into misdemeanors and felonies in concordance with Egyptian criminal law, the simple physical injuries are considered as misdemeanors which constituted half of the physical injuries reported in the present study. On the other hand, serious disabling trauma, traumatic abortion, and injuries with the intent of murder as stab and firearm injuries are considered felonies (the other half). in addition, all sexual assaults are considered felonies as well. (Sadek, 2016)

During the general examination of the potential victims, injuries were detected in only $35 \%$ of sexual assault cases. Abrasions were the most common injury in the cases with sexual crimes and limbs were the favorable sites. Similarly, Arif et al., 2014 found physical injuries in only $10.52 \%$ of their studied cases of sexual assaults. The presence of body injuries other than genital trauma potentiates the charge of sexual 
violence as assailants used force to overcome the victim resistance.

In the current study, injuries were detected in $84.3 \%$ of alleged physical assaults. Cut wounds and serious injuries were the prevalent injuries detected, while abrasions and contusions represented $37.5 \%$. That was in contradiction with Balci and Ayranci, 2005, Al-Hawari and El-Banna, 2017, and Savall et al., 2017 who stated that these minor superficial skin injuries (abrasions and contusions) represented the most common injuries detected in their study on intimate partner violence (IPV) (92\%, $71.5 \%$, and $82.7 \%$ respectively) that indicates the higher level of violence presented in the current study if compared to Turkish, Jordanian, and European populations.

In cases of physical abuse allegations, the upper limbs were the commonest anatomical site of injuries (62.5\%) followed by the head region as both areas are the most accessible sites for the offender, besides the victim used upper limbs in defense, that is in accordance with Regueira-Diéguez et al., 2015 and Savall et al., 2017 who reported that the head and upper extremities were the two preferential sites in IPV.

Burn and serious injuries such as firearm injuries and stab wounds were demonstrated only in cases of physical violence but not in sexual crimes. Though, Hagras et al., 2011 study in Egypt stated that $3.9 \%$ of sexually assaulted children reported the armed threat.

Regarding medicolegal verification of physical violence in the current research, 8 cases that represented one-quarter of the cases were self-inflicted (fabricated) wounds with false allegations. No firm evidence was reported in another eight females complained of abortion in relation to blunt abdominal trauma as from medicolegal aspect, it is impossible to differentiate between traumatic and spontaneous abortion following the evacuation of uterine contents. The rest of the cases had genuine injuries with clear medicolegal evidence of the physical assault.

In the present study, the allegations of vaginal intercourse (rape) represented more than half $(56.7 \%)$ of sexual assault claims. This was in agreement with El-Elemi et al., 2011 and Sharaf El-Din et al., 2015. Hwa et al. (2010) and Vertamatti et al., (2013) stated that the most frequent type of assault was vaginal penetration.

The hymen was intact with the absence of recent and old tears in nearly half $(48.8 \%)$ of females with an allegation of vaginal intercourse and only four cases had a recent hymenal tear. Old hymenal tears were present in 17 females who represented $41.5 \%$, though three of them were married before and the hymenal injury could not be attributed to sexual crimes.

Medicolegal opinions in relation to the hymenal integrity are critical and challenging that could prone high degrees of uncertainty in many cases. For instance, presence of intact hymen did not enough to exclude peno-vaginal penetration because the occurrence of the tear in a hymenal ring usually depends on the degree of its elasticity and dilatation, the disproportion between the male organ and vagina and the extent of force used. It is also worth mentioning that postpubertal oestrogenisation of the hymenal tissue turns it to be more elastic, resistant to injury associated with sexual assault, allowing penetration without leaving evidence as disruption or lacerations. Moreover, hymenal injuries in adolescent females could heal completely leaving no marks that denote previous penetration. (Stark.,2011, Walker.,2015) 
The recent hymenal tear usually used as solid evidence of vaginal penetration, though Vij, 2011 and Pal et al., 2018 stated that hymen could be accidentally injured in violent sports such as gymnasium and horse riding. Furthermore, the presence of old healed genital injuries along with wide vaginal orifices could allow complete intercourse without additional recent injuries. It is also important to consider normal variations in the shape of the hymen that could be misdiagnosed by inexperienced eye as traumatic lesions.

In the present study, vaginal swabs were obtained in only $60.9 \%$ of females with an allegation of rape who attended within seven days post-assault that was in concordance with the international guidelines (Ludes et al., 2018 and Recommendations FLLM, 2019).

In the present work, the spermatozoa could be detected in eight vaginal swabs of cases of alleged vaginal intercourse. Seven of them were obtained within the first 3 days of assault while the eighth one was taken in the fifth-day post-assault. The recovery of sperms from vaginal swabs with relatively long post-coital interval could be explained by the fact that semen gets longer half-life (more than 72 hours post-assault up to 5 days) with preserved sperms motility if located in cervix. This may be attributed to the acidic $\mathrm{pH}$ of the vagina which destroys the motility of sperms rapidly within 3 days. (Gould et al., 1984, Magalhães et al., 2015)

Because the rape is described as penovaginal penetration so the evidence of recent genital injuries and/or detection of spermatozoa in the vagina are the cornerstone in confirmation of vaginal intercourse. (Rege et al., 2017)

Therefore, in the present study, rape could be proved only in 14 females $(34.1 \%)$ with clear evidence, as follows; 6 positive swabs; 4 pregnancies; 2 positive swabs along with recent hymenal tear and last two cases with an only recent tear in the hymen.

Also, no firm medico-legal conclusion could be reached in nearly a quarter of alleged cases of rape because of the presence of old hymenal injuries along with wide vaginal orifices. Moreover, there was no evidence of alleged rape in a considerable number of females $(41.5 \%)$

There were several factors that could be responsible for the high negativity of sexual evidences that were reported in the current study. False allegation (true negative) should be considered along with other causes of false negativity as the delay in reporting of assault with the subsequent delay in the medico-legal examination. Also, doing certain activities post-assault like micturition, changing clothes, bathing or washings of genitals. Moreover, assailantrelated factors should be taken into consideration such as the utilization of condoms, non-ejaculation, ejaculation outside the genital area or being azoospermic. (Rege et al., 2017, Pal et al., 2018)

Regarding sodomy allegations of in the present work, no anal injuries were present in 6 females who represent nearly one-third of the cases with allegations of anal penetration whereas, recent anal tears were reported in another 6 cases and old anal fissure was present in another seven cases. All women with either recent or old anal tears had a diminished anal reflex and sphincter tone.

In the current study, anal swabs were not done in 12 cases that represented $63 \%$ from sodomy claims as they attended after three days following anal sex. The spermatozoa could be detected only in two 
cases that represent $10.5 \%$ of females and the rest of the case had negative anal swabs.

Therefore, sodomy could be proved only in seven females $(36.8 \%)$, five of them with recent anal fissures and subnormal anal tone and reflex, one case with recent anal fissure and subnormal anal tone and reflex along with positive anal swab, in addition to a case with an only positive anal swab.

While no firm medicolegal opinion could be taken in 6 cases who represented $31.6 \%$ with allegations of anal penetration because of the presence of old anal injuries along with wide anal orifices along with non-detection of spermatozoa. No evidence of anal penetration in the form of recent injuries or spermatozoa could be detected another in six females.

Interpretation of the medicolegal findings in cases with sodomy claims should be taken with great caution because anal fissures in relation to the pathological condition could be misdiagnosed as positive evidence of anal penetration. On the other hand, the anal sphincter tone and reflex along with occurrence anal injuries are critically affected by the disproportion between the penis and the anal orifice and the extent of force used that is why lubricant facilitated penetration may not induce remarkable effects. Furthermore, delayed reporting could yield false-negative results as it allows healing of injuries and loss of evidences.( Stark, 2011, Du Mont and White, 2013, Laitinen et al., 2013)

Other than rape and sodomy, nonpenetrating sexual offenses were also reported in the current study as four females with an allegation of intercrural intercourse were examined. The assault could not be proved only in one case, due to lack of any evidence of a sexual crime. Nevertheless, it could be confirmed in the other three females as spermatozoa were detected in the external vaginal swabs of two cases and the third one was presented was pregnant at the second trimester.

Furthermore, three females with an allegation of attempted rape were evaluated and the sexual offenses could not be confirmed due to lack of relevant evidence of sexual violence.

The current study revealed that evaluation of physical abuse yield more solid medicolegal opinion in most of the cases. The different physical injuries could still be assessed for a longer period even when the original injury was changed with medical intervention and/or healing process. On the contrast, the nature of genital and anal injuries was much more confusing that prone lot of uncertainties. Moreover, evidences in cases of sexual crimes were tiny and time-intensive. Therefore, rapid medicolegal assessment of the victims of sexual crimes with the cautious interpretation of findings is advisable.

On the view of the current studies the following recommendations to be considered:

- Amendment of legal procedures that allow urgent medicolegal assessment of all cases of physical and sexual assaults as soon as possible, considering them forensic emergencies with fighting against the loss of biological evidences, or occurrence of unwanted pregnancy.

- Urgent laboratory investigations to all sexually assaulted victims as routine investigations including (pregnancy test, toxicological screening together with the serological investigation of sexual transmitting diseases (STDs)

- Service delivery through forensic clinics, or and enabling direct contact to Violence against Women and Children Clinic. 
Avoiding complicated and degrading reporting procedures in police stations.

- Implementation of victim and witness protection programs with the construction of shelters for victims of abuse.

\section{REFERENCES}

Al-Hawari, H.; El-Banna, A.(2017): A medicolegal study of domestic violence in south region of Jordan. Egypt $\mathrm{J}$ Forensic Sci, 7(1):5.

DOI 10.1186/s41935-017-0006-X

Alvarado, G.; Fenny, A.; Dakey, S.; Mueller, J.; Brien-Milne, L.; Crentsil, A.; et al. (2018): The health-related impacts and costs of violence against women and girls on survivors, households and communities in Ghana. J Public Health Afr, 9(2): 860.

Arif, M.; Ahmed, M.; Chaudhary, MK. (2014): Medicolegal analysis of child and adolescent victims of sexual assault in Lahore-A retrospective study. PJMHS, 8 (2): 446-452.

Badejoko, OO.; Anyabolu, HC.; Badejoko, BO.; et al. (2014): Sexual assault in Ile-Ife, Nigeria. Niger Med J, 55(3): 254-259.

Balci, YG.; Ayranci, U. (2005): Physical violence against women: evaluation of women assaulted by spouses. J Clin Forensic Med, 12: 258-63.

Central Agency for Public Mobilization and Statistics (CAPMAS 2017 census). Available from:
http://www.capmas.gov.eg/Pages/Show PDF.aspx?page_id=\%20/Admin/Pages \%20Files/2017109143840cns.pdf.

Du Mont, J.; White, D. (2013): Barriers to the Effective Use of MedicoLegal Findings in Sexual Assault Cases Worldwide. Qualitative Health Research, 23(9): 1228 -1239.

Egyptian council of women, Egypt violence against women study a summary of findings (2015). Available from: https://www.cepal.org/mujer/noticias/pa ginas/7/42837/internallink_EGYPT_VI OLENCE.pdf

El-Elemi, AH.; Moustafa, SM.; Hagras, AM. (2011): Reported cases of female sexual assault over 5 years period in Suez Canal area, Egypt: demographic study. Egypt J Forensic Sci, 1:118-123.

Gould, JE.; Overstreet, JW.; Hanson, FW. (1984): Assessment of human sperm function after recovery from the female reproductive tract. Biology of Reproduction, 31 (5): 888-894.

Guedes, A.; Bott, S.; Garcia-Moreno, C. et al. (2016): Bridging the gaps: a global review of intersections of violence against women and violence against children. Glob Health Action, 9: 10-13.

Hagras, AM.; Moustafa, SM.; Barakat, HN.; El-Elemi, AH. (2011): MedicoLegal evaluation of child sexual abuse over a six-year period from 2004 
to 2009 in the Suez Canal area, Egypt J Forensic Sci, 1: 58-66.

Hassan, Q.; Bashir, MZ.; Mujahid, M.; Munawar, AZ.; Aslam, M.; Marri MZ. (2007): Medico-legal assessment of sexual assault victims in Lahore. J Pak Med Assoc, 57(11): 539-542.

Hilal, MA.; Mohamed, SA.; AboulHggag, KE. (2006): Sexual assault in Sohag Governorate in two years (20022003). Sohag Med J, 10 (1): 264-274.

Hwa, HL.; Chen, SC.; Wu, MZ. et al. (2010): Analysis of cases of sexual assault presenting at a medical center in Taipei.Taiwan J Obstet Gynecol, 49: 165-169.

Hwang, KR.; Han; KY.; Shin, MS. et al. (2010): A study of sexual assault: based on data from Boramae One-stop Service Center.J Womens Med, 3(3): 96-101.

Jänisch, S.; Meyer; H.; Germerott, T.; Schulz, Y.; Albrecht, UV.; Schmidt, A.; Debertin, AS. (2010): Analysis of clinical forensic examination reports on sexually abused children. Arch Kriminol, 225(1-2):18-27.

Jaworska, N.; MacQueen, G. (2015): Adolescence as a unique developmental period. J Psychiatry Neurosci, 40(5): 291-293.

Kernbach-Wighton, G. (2014): Intimate Partner and Domestic Violence. In: Burkhard Madea. Handbook of Forensic Medicine. $1^{\text {st }}$ edition, Germany; John Wiley \& Sons, Ltd.; 746-750.
Laitinen, FA.; Grundmann, O.; Ernst, EJ. (2013): Factors that influence the variability in findings of anogenital injury in adolescent/adult sexual assault victims: a review of the forensic literature. Am J Forensic Med Pathol, 234(3): 286-94.

Laukkanen S. Sexual violence and medico and legal linkage (2014). Available from: https://www.gfmer.ch/SRHCourse-2013/Geneva-

Workshop/pdf/Sexual-violence medicolegal-linkage-Laukkanen-2014.pdf

Ludes, BA.; Geraut, A.; Väli, M.; Cusack, D.; Ferrara, D.; Kelle, E. et al. (2018): Guidelines examination of victims of sexual assault harmonization of forensic and medico-legal examination of persons. Int J Legal Med, 132(6):16711674.

Magalhães T, Dinis-Oliveira RJ, Silva B, Corte-Real F, Vieira DN. (2015): Biological Evidence Management for DNA Analysis in Cases of Sexual Assault. Scientific World Journal, Article ID 365674: 1-11. http://dx.doi.org/10.1155/2015/365674

McLean, I. Climatic effects on incidence of sexual assault. (2007): J Forensic Leg Med, 14:16-19.

Owusu-Addo, E.; Owusu-Addo, SB.; Antoh, EF.; Sarpong, YA.; ObengOkrah, K.; Annan, GK. (2018): Ghanaian media coverage of violence against women and girls: implications for health promotion. BMC Womens Health, 18(1):129. 
Pal, SK.; Rana, A.; Sharma, A.; Sehgal, A. (2018): Forensic Study of Child Sexual Abuse in Northern Range of Himachal Pradesh, PRJFGS 1(3): 3843.

Recommendations for the collection of forensic specimens from complainants and suspect. (2019): Faculty of Forensic and Legal Medicine FLLM, the Royal College of Physicicains. Available from: http://www.fflm.ac.uk/publications/proforma-forensic-medical-examinationforms $2 /$ ).

Rege S, Bhate-Deosthali P, Reddy JN. (2017): Medico-legal aspects of sexual violence: Impact on court judgments. JFRA, 1 (1): 1-7.

Regueira-Diéguez, A.; Pérez-Rivas, N.; Muñoz-Barús, JI.; VázquezPortomeñe, F.; Rodríguez-Calvo, MS. (2015): Intimate partner violence against women in Spain: A medicolegal and criminological study. Forensic Leg Med, 34:119-126.

Riggs, N.; Houry, D.; Long, G.; Markovchick, V.; Feldhaus, KM. (2000): Analysis of 1076 cases of sexual assault. Ann Emerg Med, 35: 358-62.

Sadek, G. Egypt: Sexual Violence Against Women. (2016): The Law Library of Congress, Global Legal Research Center; 1-22. Available from: https://www.loc.gov/law/help/sexual- violence-against-women/egypt-sexualviolence-against-women.pdf.

Santos, JC.; Neves, A.; Rodrigues, M.; Ferrao, P. (2006): Victims of sexual offences: Medicolegal examinations in emergency settings. J Clinical Forensic Med, 13: 300-303.

Savall, F.; Lechevalier, A.; Hérin, F.; Vergnault, M.; Telmon, N.; Bartoli, C. (2017): A ten-year experience of physical Intimate partner violence (IPV) in a French forensic unit. Forensic Leg Med, 46: 12-15.

Sharaf El-Din, A.; Elkholy, S.; Metwally, E.; Farag H. (2015): Pattern of Female Sexual Assault in Qalyubia Governorate, Egypt, During the Period From 2009 to 2013. A Retrospective Study. Am J Forensic Med Pathol, 36 (4): 276-284.

Stark M. Clinical Forensic Medicine.( 2011): $3^{\text {rd }}$ Edition. UK: Humana Press; 71-130.

Steine, IM.; Krystal, JH.; Nordhus, IH.; Bjorvatn, B.; Harvey, AG.; Eid, J. et al. (2012): Insomnia, nightmare frequency, and nightmare distress in victims of sexual abuse: The role of perceived social support and abuse characteristics. JIV, 27(9): 1827-1843.

Sukul, B.; Chattopadhyay, S.; Bose, TK. (2009): A study of victims of natural sexual offence in the Bankura district of West Bengal. J Indian Acad Forensic Med, 31(1): 25-29. 
UN Human Rights. Global Database on

Violence against Women, Egypt (2019). Available from: http://evawglobal-

database.unwomen.org/fr/countries/afric a/egypt

UN Women New York, (2012). Available from:

https://www.un.org/womenwatch/daw/v aw/handbook-for-nap-on-vaw.pdf

Vertamatti, MF.; De Abreu, LC.; Drezett, J. et al. (2013): Time lapsed between sexual aggression and arrival at the Brazilian health service. J Hum Growth Dev, 23(1):46-51.

Vij, K. Textbook of Forensic Medicine and Toxicology: Principles and Practice. (2011): $5^{\text {th }}$ edition. India: Reed Elsevier India Private Limited; 314-319.

Violence Against Women In Politics.Expert Group Meeting Report \& Recommendations, New
York (2018). Available from: https://www.ohchr.org/Documents/Issue s/Women/Violence Against Women in Politics Report.pdf

Walker, G. (2015): The (in)significance of genital injury in rape and sexual assault. J Forensic Leg Med, 34:173-8.

White, C.; McLean, I. (2006): Adolescent complainants of sexual assault; injury pattern in virgin and non-virgin groups. J Clin Forensic Med, 13(4):172-80

World Health Organization. Violence against women (2017). Available from: https://www.who.int/news-room/factsheets/detail/violence-against-women

Yount, KM.; Krause, KH.; Miedema, SS. (2017): Preventing gender-based violence victimization in adolescent girls in lower-income countries: Systematic review of reviews. Soc Sci Med, 2017;192:1-13. 


\title{
الملخص العري؟
}

\section{التقييم الطبي الشـرعي لإدعاءات الإعتداءات البدنية والجنسيّة للإناث} المراهقات و البالغات المحالات لقسم الطب الشرعحي بوزارة العدل في الإسكندرية: دراسة مستقبلية.

\author{
زهراء خليفة صبح"، أسماء سعيد البناث*، هبة محمد منيسي **** \\ مدرس الطب الثرعي و السموم الإكلينيكية، كلية الطب، جامعة الإسكندرية \\ * * أستاذ مساعد الطب الثرعي و السموم الإكلينيكية، كلية الطب، جامعة الإسكندرية \\ ***رئر وحدة العنف ضد المرأة و الطفل، قسم الطب الثرعي بوزارة العدل في الإسكندرية
}

المقدمة : العنف ضد المر أة هو جريمة عالمية تتخطى الحدود الثقافية والدينية و تنتهك الحقوق الإنسانية للإناث. و تهدف الدر اسة الي تقييم إدعاءات الإعتداءت البدنية و الجنسية للإناث المر اهقات و البالغات.

المشاركون والأساليب: در اسة مستقبلية شملت جميع الإناث فوق سن ب ا عامًا الذين تم إحالتهن إلى قسم الطب الثر عي بوز ارة العدل في الإسكندرية لتقييم مز اعم الإعتداء البدني و الجنسي خلال فترة 7 أنشهر

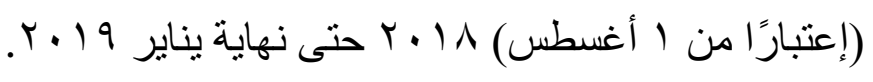

النتائج: تمت في هذه الدر اسة مناظرة ب 9 أنثى من اللاتي زعمن تعرضهن للعنف ( • ا حالة إعتداء جنسي و

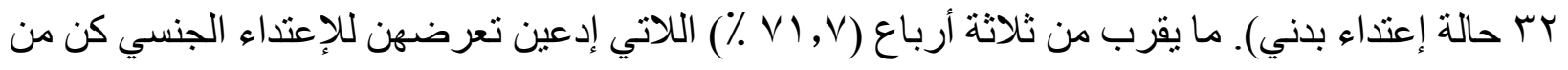

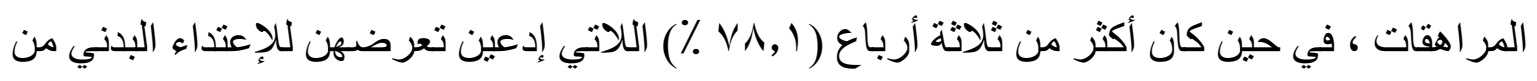

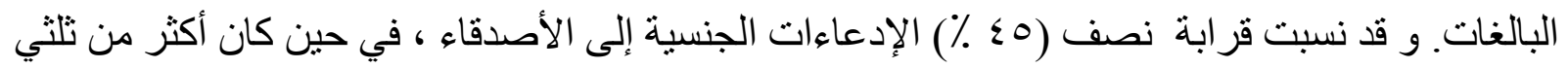
(\% حالات العنف البدني داخل نطاق الأسرة.

و لقد كان نصف مز اعم العنف البدني على هيئة جروح بسيطة بينما كان النصف الآخر علي هيئة إصابات خطيرة في صورة إجهاض إصابي و إصابات طعنية و نارية. أما بالنظر إلى الإدعاءات الجنسية ،فقد شكل هلئل

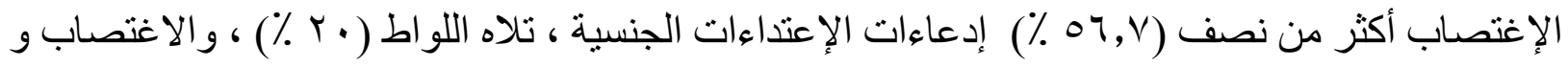

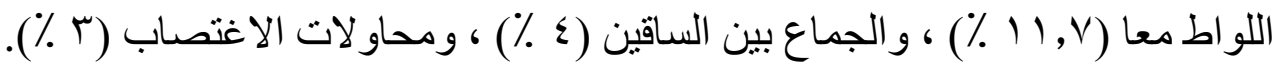


فيما يتعلق بالشو اهد الطبية الثر عية ؛ تبينت أدلة و اضحة للإعتداء في ه ٪ و ر,ه ٪ من إدعاءات

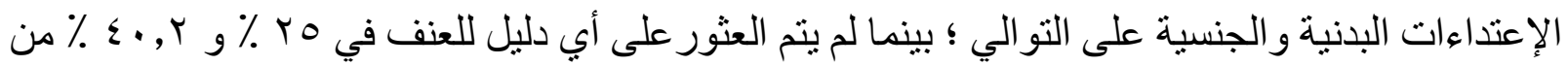
إدعاءات الإعتداءات البدنية والجنسية على التو الي. كما أنه لم يكن هنالك دليل حاسم علي وقوع الإعتداء المزعوم مع جو از حدوثه في هץ ٪ و ^, ؟r ٪ من الإدعاءات البدنية والجنسية على التو الي. الإستتناجات: تقييم الإعتداء الجسدي غالبا ما ينشأ عنه رأى طبي شر عي حاسم في معظم الحالات. على

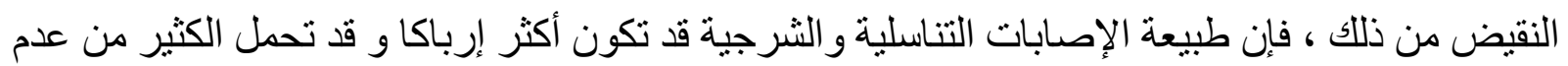
التيقن. لذلك ، ينصح بإجر اء تقييم طبي شر عي عاجل لضحايا الجر ائم الجنسية مع التفسير الحذر للنتائج. 